\title{
PEDAGOGICAL PRACTICES OF GOOD NURSING, MEDICINE AND DENTISTRY PROFESSORS FROM THE STUDENTS' PERCEPTION ${ }^{1}$
}

\author{
Jouhanna do Carmo Menegaz², Vânia Marli Shubert Backes³, José Luiz Medina4, Marta Lenise Prado5 , Bruna \\ Pedroso Canever ${ }^{6}$
}

\begin{abstract}
${ }^{1}$ Extract from the thesis - Practices of good teachers of nursing, medicine and dentistry in the perception of students, presented to the Pós-Graduação em Enfermagem (PEN) of the Univerisidade Federal de Santa Catarina (UFSC) in 2012.

${ }^{2}$ Doctoral Student, PEN/UFSC. CNPq fellow. Florianópolis, Santa Catarina, Brazil. E-mail: jomenegaz@gmail.com

${ }^{3}$ Ph.D. in Nursing. Professor at the Curso de graduação em Enfermagem and at PEN/UFSC. CNPq researcher. Florianópolis, Santa Catarina, Brazil. E-mail: oivania@nfr.ufsc.br

${ }^{4}$ Ph.D. in Philosophy and Education Sciences. Professor at the Faculdad de Pedagogia de la Universidade de Barcelona. Barcelona, Spain. E-mail: jlmedina@ub.edu

${ }^{5}$ Ph.D. in Nursing. Professor at the undergraduate nursing course and at PEN/UFSC. Florianópolis, Santa Catarina, Brazil. E-mail: marta.lenise@ufsc.br

${ }^{6}$ Doctoral Student PEN/UFSC. Pró-Ensino na Saúde fellow. Florianópolis, Santa Catarina, Brazil. E-mail: brunacanever@gmail.com

ABSTRACT: The aim of this qualitative study was to analyze, in the light of Shuman's concept of pedagogical content knowledge, the pedagogical practices of good nursing, medicine and dentistry professors from the perception of students of a public university in southern Brazil. The study comprised 16 students who were approached through interviews focused by vignettes and qualitative indicators. Pedagogical content knowledge is observed when good professors share the learning objectives while associating theory and practice, fostering student reasoning using a wide range of strategies responsive to contents and the public; carefully prepare and organize their lessons; and allow to be evaluated. Pedagogical content knowledge is presented as a differential in teaching practice; however, students perceive these practices in few professors, leading to the need for recommending rooms and strategies for training health teaching staff. DESCRIPTORS: Students. Teaching. Faculty nursing. Faculty medical. Faculty dental.
\end{abstract}

\section{PRÁTICAS PEDAGÓGICAS DE BONS PROFESSORES DE ENFERMAGEM, MEDICINA E ODONTOLOGIA NA PERCEPÇÃO DOS ESTUDANTES}

RESUMO: Estudo qualitativo que teve como objetivo analisar, à luz do conceito de conhecimento pedagógico de conteúdo de Shulman, práticas pedagógicas de bons professores de enfermagem, medicina e odontologia, na percepção de estudantes de uma universidade pública do Sul do Brasil. Participaram do estudo 16 estudantes, entrevistados com auxílio de entrevista focalizada por vinhetas e indicadores qualitativos. O conhecimento pedagógico de conteúdo se mostra presente quando bons professores compartilham os objetivos de ensino ao mesmo tempo em que estabelecem conexão entre teoria e prática, por meio do fomento do raciocínio do estudante utilizando-se de uma diversa gama de estratégias adequadas aos conteúdos e ao público; preparam e organizam suas aulas com esmero; e permitem-se ser avaliados. O conhecimento pedagógico de conteúdo se apresenta como diferencial na prática docente, entretanto, poucos são os professores em quem os estudantes percebem estas práticas, sendo necessária proposição de espaços e estratégias de formação docente em saúde.

DESCRITORES: Estudantes. Ensino. Docentes de enfermagem. Docentes de medicina. Docentes de odontologia.

\section{LAS PRÁCTICAS PEDAGÓGICAS DE BUENOS PROFESORES DE ENFERMERÍA, MEDICINA Y ODONTOLOGÍA EN LA PERCEPCIÓN DE ESTUDIANTES}

RESUMEN: Este estudio cualitativo tuvo como objetivo analizar a la luz del concepto de conocimiento pedagógico del contenido de Shulman prácticas pedagógicas de buenos profesores de enfermería, medicina y odontología en la percepción de los estudiantes de una universidad pública en el sur de Brasil. Los participantes del estudio fueron 16 estudiantes entrevistados con la ayuda de la entrevista focalizada en viñetas e indicadores cualitativos. El conocimiento del contenido pedagógico muestra esto cuando los buenos profesores comparten los objetivos de aprendizaje mientras se establece la conexión entre la teoría y la práctica, fomentando el razonamiento de los estudiantes usando una amplia gama de estrategias adecuadas a los contenidos y público; prepararan y organizan sus lecciones con cuidado y permiten ser evaluados. El conocimiento didáctico del contenido se presenta como un diferencial en la práctica docente, sin embargo, son pocos los profesores que los estudiantes perciben con estas prácticas, siendo necesaria la propuesta de espacios y estrategias de formación docente y en salud.

DESCRITORES: Estudiantes. Enseñanza. Docentes de enfermería. Docentes de medicina. Docentes de odontología. 


\section{INTRODUCTION}

In the last decade Brazil experienced huge changes in health education in response to the need for ruling and organizing health education based on the principles and demands of the Brazilian Unified Health System (SUS). Regardless the relevance of actions developed up to now, when it comes to shift health education most efforts are focused on students and health workers. ${ }^{1}$

Little emphasis is placed on shifting or, better said, guiding the education of professors, considering that most of times they lack initial training for teaching ${ }^{2}$ or, following the public policies on graduate education, are educated in the stricto sensu modality, which prioritizes research. This factor is highlighted as the reason for several deficiencies of pedagogical nature..$^{3-4}$

The acknowledgement of professors, notably their pedagogical practice that goes beyond professional competence, plays a crucial role in this context of longing for changes in health education. For being such a complex task, the teaching work demands specific knowledge and training. ${ }^{5}$ In this sense, some researchers have approached studies on teaching training, ranging from the teaching training process to elements that should be part of it.

Among these studies, we highlight that by Lee Shulman, ${ }^{6}$ which reviews the teaching practice and its impact on the learning and teaching development through some constructs: sources of teaching knowledge base; categories of teaching knowledge base; and, the Model of Pedagogical Reasoning and Action.

The sources of teaching knowledge base are: 1) scholarship in content disciplines; 2) pedagogical structures and materials; 3) specialized bibliography; and, 4) knowledge acquired through teaching practice. The knowledge base for teaching is divided into seven knowledge categories that support excellent teaching practice, as follows: 1) content knowledge; 2) general pedagogical knowledge; 3) pedagogical content knowledge; 4) curriculum knowledge; 5) knowledge of educational contexts; 6) knowledge of learners and their characteristics; and, 7) knowledge of educational ends, purposes and values, and their philosophical and historical grounds.

These categories are fostered by the initial and continuous training of professors, and support the so-called Model of Pedagogical Reasoning and Action. ${ }^{7}$ This model represents the professors' process of building their practices and thinking over these, being characterized by the following phases: 1) comprehension; 2) transformation; 3) instruction; 4) evaluation; 5) reflection; and, 6) new ways of learning, mobilizing and developing teaching knowledge base through reflective teaching practice.

As professors go through the phases they undergo moments of pedagogical practice, from understanding the content they want to share until the teaching moment itself, reaching the process of evaluation and resignification of the event for the professor. ${ }^{7}$ In this process imbued with reflection, professors resource to all knowledge base categories. When interacting with students, the most evident and noticeable category is the pedagogical content knowledge (PCK).

This knowledge base category stands for the professor's capacity of, in a varied and contextualized way, making students understand topics and contents unknown to them up to that time. It summarizes the professor's capacity of articulating the remainder categories of knowledge base to teach in a responsive way to the educational moment and training demands. It is likely to be the category that allows distinguishing the knowledge held by a master from the knowledge held by an expert. ${ }^{7}$

In this sense, considering the curiosity about how professors have developed their pedagogical practice, and despite the limitations of initial and permanent training, understanding that students' perception about good professors could serve as a reference point for interesting reflections about the impact of the changes occurring in education and highlighting the investigation of professors' training in the scenario of health training shift, the aim of this study was to analyze, in the light of Shulman's ${ }^{7}$ concept of pedagogical content knowledge, the pedagogical practices of good nursing, medicine and dentistry professors, from the perspective of students from a public university in the southern of Brazil.

\section{METHOD}

Qualitative study with exploratory-analytical approach, developed in a public university in the southern of Brazil, comprising six undergraduate students completing the nursing course, five completing the medical course and five completing the dentistry course, totaling 16 participants intentionally selected from the networked sample.

Teaching knowledge base categories were elected as the theoretical frame for the study. 
Here, we have selected four of seven categories: content knowledge; pedagogical content knowledge; knowledge of learners and their characteristics; knowledge of educational ends, purposes and values, and their philosophical and historical grounds; ${ }^{7}$ and, general competences of the Brazilian National Curricular Guidelines (DCN - Diretrizes Curriculares Nacionais): health care; permanent education; decision-making; leadership; communication and administration; and, management. ${ }^{8}$ The teaching knowledge base categories were selected because the author highly appraises the knowledge acquired through teaching practice per se in a given social place. This fact is particularly relevant in a setting of educational changes, with few actions focusing on teaching training. Another reason would be that professors can learn through individual and volunteer access to the knowledge base sources, notably the knowledge acquired through teaching practice. $^{7}$

The selection is also due to the fact that we share the author's viewpoint on the need for a set of knowledge mobilized in a movement and reflection, expressed through the PCK, to reach the educational objectives socially agreed on and expressed in public policies. This justifies the coordination between teaching knowledge base and general competencies of the national curricular guidelines. The coordination with the DCN general competencies as theoretical frame is pertinent, as the DCN approach the abstract concepts of the knowledge base categories in the reality investigated. Moreover, the guidelines are an element that promotes integration among the courses surveyed.

Based on the theoretical frame established, vignettes were created and named according to each knowledge base category selected to the study. The four vignettes described a good professor based on the relevant knowledge base and supported by the general competencies described in the DCN. The vignettes were part of a script of the focus interview used for data collection.

Nursing, medical and dentistry courses were selected because the perception of students about their professional categories is of utmost relevance to their work, and these courses are the focus of most of the governmental policies on university education. To be selected, participants should meet the following criteria: being enrolled at the last term of the undergraduate courses surveyed; being indicated by another student. The exclusion criteria considered students that would not com- plete the course in the semester of data collection, and those participating in exchange programs that were in the last semester of the course but did not belong to the educational institution. The number of participants was defined based on the concept of theoretical saturation of data perceived as interviews were performed, transcribed and analyzed.

The researchers initially contacted the coordinators of the courses, presented the study, and asked them for permission to contact the class representatives. Participants were invited by e-mail, and an individual conversation was scheduled to present the study and its objectives and invite students to participate. After the students agreed on and signed the Free and Informed Consent Term, the interview was carried out.

Interviews were individual and at a site selected by students. First, the participant received and read the vignette printed on A4 paper. After reading, participants were questioned about their perceptions on the text, and how close or far the report was from their perception about the practice of good professors. The conversation was recorded and transcribed. By the end of the interview, students were invited to nominate two classmates and inform their contacts, so they could be invited to participate in the study, thus building the networked sample.

After being transcribed, interviews were analyzed based on the operational proposal. ${ }^{9}$ The analytical categories emerged from the theoretical framework. This text highlights the analytical process displayed in the vignette related to PCK, i.e., one of the four vignettes of the study. As the selected data collection method was the focused interview with vignettes and indicators, few categories emerged and the links with analytical categories pre-established by the knowledge base categories were stronger.

Three categories emerged from the analysis ${ }^{9}$ of the PCK-related vignette: 1) students' dialogue skills and engagement in teaching-learning activities; 2) capacity of associating contents and selecting teaching strategies pertinent to the needs of professional training; and, 3) planning, organization, conduction and evaluation of the teaching strategies elected.

The research proposal was approved by the Research Ethics Committee (protocol 2317/2011) and complied with the ethical principles established by Resolution 196/96 of the Brazilian Health Council. In order to ensure the anonymity of participants in the section of results, we used 
the letters N, M, D to correlate the speech to the student's course, followed by the numerical record assigned during the codification process.

\section{RESULTS}

In the category "Students dialogue skills and engagement with teaching-learning activities", the speeches strongly displayed perceptions about the pedagogical positioning of the professors. Students perceived that a good professor is guided by a horizontal relationship, with goodwill to joint learning. Good professors enjoy sharing the learning process, respect students' experiences and knowledge, and do not assume that students know nothing.

We usually see the professor coming into class assuming that students hold zero knowledge. This is very common in early phases. I remember when we got into a class on muscle and histology, that started at 8am, knowing absolutely nothing about muscle, and got a theoretical class for four hours, and I don't know the purpose of getting someone who knows nothing about muscle at 8am and make him leave at noon as an expert on muscle. After 40 minutes of class, no one could learn anything else. And here it makes a difference when the professor is more relaxed, sits near us rather than staying there, near the board, and says: 'Today we'll talk about this. What do you know about it? What have you seen about it? What do you understand about it?' I guess this is, by itself, a non-conventional way (M2R34).

To that, they recognize their personal limitations and limited knowledge, respecting the students' limitations, teaching with partnership, respect and willingness for dialogue in and out of the classroom.

And also this thing of bringing this reality of context, of the SUS, of making us think always building a link. This thing of making everyone comfortable near you, free to make questions knowing they won't be criticized, with no fear of asking, I guess this is very important, and having a partnership, we are building together, no one is passing on anything, we are building knowledge, my knowledge, your knowledge, and everyone is learning, both me and the professor, there is an exchange (N5R142).

During interview, students expressed concern about their need of finding out if what they were learning had to do with what they would experience in their professional practice. In this sense, the expression "link theory and practice" was frequent in the speech of students, evidenc- ing their perception that a good professor is also clear about the objectives of the subject and the relevance of given content in the context of professional training, providing students not only with access to information but also with the capacity of thinking over and criticizing that information.

I like when the professor somehow links theory and practice. Of course we learn much more in theory, but not everything... I myself, who am completing the course, in practice I have not found everything I've learned in theory, there is a wide range of situations, but I guess it makes us memorize, because sometimes we get lost, 'But how will I do it ?' (D1R19).

Regarding "Capacity of associating contents and selecting teaching strategies pertinent to the needs of professional training", apart from the students' demand for knowing if what they are learning will "skill" them to work with professional competence in health scenarios as presented in the previous category, students have expressed that, additionally to this characteristic, a good professor does something they believe to be extremely relevant: encourages thinking.

For that, they make use of several resources to correlate content and current aspects and issues, and the future professional practice. The students' opinions about the most valid strategies have widely varied. For example, medicine students emphasized the discussion of clinical cases, not necessarily followed by media projector presentation. Dentistry students, in turn, appraised the use of media projector, mainly when professors use pictures to illustrate what they are saying. Nursing students referred to playful activities such as films, videos, text discussions.

It is about knowing that we have lots of resources today to show whatever we want, and I guess sometimes playing a video is better, sometimes showing a slide is better, sometimes the good and old board, write something, sometimes not showing anything is better, just sitting and talking, sometimes taking students somewhere to show them what they must see... If in the physical exam you have to learn techniques to exam a liver, there is no use in watching a video. You have to go there and do it. I believe professors should know which resources are to be used by that time (N2R44).

However, despite differences regarding resources, there is a consensus about the fact that interaction is the key element for the successful use of the resource. Interaction between professor and students, and among students. A widely quoted example was the planning of dilemmatic situations based on real situations demanding analysis, good 
sense and recovery and integration of knowledge previously acquired.

It makes all the difference a professor who asks: 'And now? What would you do now?' Because medicine, I don't know about nursing and other areas, but medicine is all about clinical reasoning, and we are always working with diagnosis and treatment. But how diagnosis is made is poorly approached in the course. Professors who work it well, how to get there, end up by being a differential (M3R92).

Another important aspect highlighted by students refers to the fact that, apart from using the aforementioned resources, professors should know how to select the proper resource to each type of content, according to each class or even according to what a given student needs to learn, being capable of making use of a wide range of resources to teach a topic until students understand it.

The class was not conventional, it was different exactly for that, because it was attractive and had strategies. I think it is important, making each class different from the other and counting on different strategies to teach the same subject, i.e., used a text, student didn't understand, makes a question, draws, writes again, plays a video, got it? I think there are several ways of teaching something, and each person learns in a different way, so if [the professor] has several strategies, it will really facilitate (D5R202).

In the category "Planning, organization, conduction and evaluation of the teaching strategies elected", additionally to the reasons disclosed in the first category, students consider it important feeling that the professor carefully plans classoriented lessons and approaches comprising current and relevant aspects of the topic in question.

To me, it is essential that professors plan lessons to show you the ways, guide the ways. They must make us think, then walk with our own legs, but always based on theory, always based on science, never only on practical activities, always based on evidence, some professors may even fail in doing that 'Oh, but I've always done that way and it always worked well' (D3R9).

They have also pointed out that, additionally to these aspects and the interaction and resources used, professors must allow students to evaluate the session or subject not only regarding the content, but also regarding how and how effectively they teach.

In my view, what is really terrible in a class, extremely boring, is the professor reading PowerPoint slides. I can read slides at home. I don't need anyone reading them for me. And it happens a lot. The person is very busy, we understand it. They are low-paid, must have more than one job, all that thing (M4R92).

\section{DISCUSSION}

It was observed that students recognized as good professors those adopting practices that reflected freeing pedagogical model and posture rather than an authoritarian approach. This is clearly a crucial element in a process of educational changes intended to nurture more active students that effectively participate in their own education. In the Brazilian context of health education, the DCN provide for that. More directive models are less likely to promote the nurturing of creative, active, and critical professionals. ${ }^{8,10}$

According to Shulman, ${ }^{7}$ although the professor's preference for one or other class format, for this or that teaching strategy is considered to be pedagogical content knowledge in teaching practice. These selections are supported by another category of teaching knowledge base, known as pedagogical general knowledge (PGK). This category stands for the overall knowledge of professors about teaching and learning, about the role played by professors and students and, thus, often unconsciously guides professors' decisions. In the lack of pedagogical training, the PGK is built based on previous experiences as students and as professors. It is a replication of models considered to be adequate and successful., ${ }^{71}$

In the same sense, when students consider as good professors those encouraging them to think, they show interest in becoming authors of their own knowledge, developing skills that would strengthen their competence of providing health care and making decisions. Health professionals must perform these actions in their everyday professional lives, and those skills are not built overnight. ${ }^{9}$

Hence, the role played by the PGK in the expression of the PCK should be emphasized, since a more comprehensive, relational and less directive understanding about teaching and learning, and about the role of students and professors will influence on the professors' selection of pedagogical strategies that follow the same path. Thus, the strategies and their features can simultaneously demonstrate the professor's PCK degree and the development of the remainder categories of teaching knowledge base.

To express the PCK or, as students say, to be capable of using a wide range of didactic re- 
sources responsive to training 8 demands and to meet the educational needs of students, professors must hold not only PGK but also sound content knowledge, knowledge of learners and their characteristics, curriculum knowledge, knowledge of educational contexts and knowledge about the educational ends, purposes, values and their historical-philosophical grounds. ${ }^{7}$

Even if some of these knowledge base categories have not been perceived by students in their good professors, either because of the division of the study into four categories or because some categories are less tangible to others, these are part of the mixture that results in the aforementioned practice. Thus, when analyzing the practices focused herein, one should understand these in a broader scope, in the heart of a process that coordinates all categories of teaching knowledge base.

The strategies and resources used by good professors are correlated with the findings of other studies, and reflect the association of content knowledge, knowledge of learners and their characteristics and the PCK, notably when referring to the proper use of such strategies and resources in line with the content, and the capacity of diversifying these. ${ }^{12-13}$

The perception that good professors use analogies, anecdotes and examples, referred to by students as resources that link theory and practice, is interesting in the pedagogical light, as these resources bear the potential of raising interest and building significant learning. Likewise, these resources have potential to clarify the relevance of a given topic in the context of work and this is very relevant considering the value generally assigned by student to the development of knowing how to do things. ${ }^{14-15}$

Although this text aims at exploring the practices that reveal PCK, it is worth mentioning the link with the remainder categories of teaching knowledge base. Regarding this datum on the valuation of pedagogical approaches that help associating theory and practice, professors should bear not only PCK, but should also know the educational ends, purposes and values and their historical-philosophical grounds.

This is the category of knowledge base that, in the context of the Brazilian health education ${ }^{8}$, stands for the professors' knowledge about the theoretical and philosophical grounds of health education, and the knowledge about the intended professional profile. This way, the association of both categories of knowledge, PCK and knowl- edge about objectives, is relevant ${ }^{6}$ as it aligns the selection of an efficient pedagogical resource to the fostering of educational competences that are socially desired and expressed in policies and guidelines on education. $^{7}$

Moreover, students perceive as important the association between PGK and knowledge of learners and their characteristics, which is another knowledge base category that stands for the professors' knowledge about who their students are, what they know, and their best ways of learning. As can be observed from reports, more than a pedagogical posture of respect and sharing, it is a pedagogical resource important to get to know students as it provides the required information for professors to make the reflection process profitable for students in the context of the curriculum and competencies they must develop about a given topic. $^{7}$

This sophistication perceived by students not only in the process of selecting the pedagogical resources, but also in the use of those resources, expresses the PCK. However, it is worth recalling that the development and perception of PCK, considered by students as the professors' capacity of providing the resources and skills required to learn in different settings and in different ways, ${ }^{5}$ is not only PCK per se, but teaching knowledge base. ${ }^{7}$

Hence, the lack of diversity of pedagogical resources and a more collaborative pedagogical posture perceived by students in the practice of most professors may be related to poor teaching training, which limits the development of teaching knowledge base categories as a whole since, among others, this development takes place through the reflective teaching practice. ${ }^{7}$

Another practice perceived by students and that evidences PCK is the practice of sharing objectives, teaching strategies, and listening to the students' opinion about the effectiveness of those practices. This could increase the students' interest in the class and improve their understanding about their teaching and learning process, encouraging them and contributing to understand the role of each content, each stage of their education to outline the professional profile, and awake the desire for permanent education. Likewise, this initiative by professors collaborates to the improvement of their own practice, increasing the sophistication of their resources and pedagogical approaches. ${ }^{7}$ It is also worth mentioning that, in the perception of some students, professors should also be personally and professionally involved with stu- 
dents. These aspects demand the use of ways and strategies that transform their knowledge and help leading the nurturing of future professionals. ${ }^{16-17}$ This is a controversial issue about the role played by professors, and goes beyond the PCK concept since it implies not only teaching training, but also the willingness for deeper and more personal involvement by professors.

Students perceived the importance of content knowledge (being updated); general pedagogical knowledge and pedagogical content knowledge (the pedagogical posture and resources selected); knowledge about learners (preparation of class-based material) in the practice of their best professors. Even in a tacit way, the six phases of the Model of Pedagogical Reasoning and Action were evidenced since, in the students' perception, in order to teach professors must understanding and change, evaluate their practices, think over and find new ways of understanding and doing things in a dynamic and endless cycle grounded on the premise of enhancing teaching knowledge base, notably the PCK, thus gradually improving the teaching practice. ${ }^{18-19}$

\section{FINAL CONSIDERATIONS}

The practices perceived by the nursing, medicine and dentistry students in their best professors are laid on the pedagogical content knowledge and are in line with the demand for a new health education that nurtures empowered and creative professionals, capable of assisting the SUS consolidation.

However, these pedagogical practices are not perceived in most professors, leading to the need for investing in initial and permanent teaching training. Based on the speeches of students, we find that not only pedagogical content knowledge was present, but virtually all categories of knowledge base were mentioned. This strengthens the view that competent education, guided by theSUS and focusing on the development of the competences set out in the curricular competences, could serve as ground to the intended shifts in health education.

In this sense, we understand that current teaching training is required to go farther than developing one or another category of teaching knowledge base, and become a process of development of all categories of knowledge, since pedagogical content knowledge can only be effectively developed in the presence of comprehensive knowledge base. Telling professors that the use of this or that pedagogical resource is efficacious is not enough if they do not develop the capability of thinking over and adjusting resources to contents, students, curricula, contexts and development objectives.

New and old practices will co-exist in the education setting, potentially leading to gaps in the development of the general competences of graduates until a broader formative conception is materialized, i.e., until teaching training is no longer considered just as assimilating a given way of teaching or the presence of graduate degrees.

The abovementioned reinforces the relevance and urgent need for studies and reflections about health teaching education to recommend policies and programs capable of fostering changes in the way professors think and do, not only at an individual level, but also with potential collective impact, fostering the development of a permanent culture of teaching training.

New studies with that framework should be developed, and the findings of this study should be considered, respecting the limitations of a study carried out in an education institution and based on the students' perception about their professors.

\section{REFERENCES}

1. Ministério da Saúde (BR). Plano Nacional de Saúde 2012-2015. Brasília (DF): MS; 2011.

2. Instituto Nacional de Pesquisa Anísio Teixeira. Resumo Técnico do Censo da Educação Superior 2011. Brasília (DF): INEP; 2013.

3. Backes VMS, Prado ML, Moya JLM. The construction process of pedagogical knowledge among nursing teachers. Rev Latino-Am Enfermagem. 2011; 19(2):421-8.

4. Coordenação de Aperfeiçoamento de Pessoal de Nível Superior. Plano Nacional de Pós-Graduação. Brasília (DF): CAPES; 2010.

5. Nuangchalerm P. Enhancing pedagogical content knowledge in preservice science teachers. Higler Educ Stud. 2012; 2(2):66-71.

6. Bailey LB. The impact of sustained, standards-based professional learning on second and third grade teachers' content and pedagogical knowledge in integrated mathematics. Early Childhood Educ J. 2010; 38(2):772-86.

7. Shulman L. Conocimiento y enseñanza: fundamentos de la nueva reforma. Profesorado Rev Curriculum Formación del Teacherado. 2005; 9(2):1-30.

8. Conselho Nacional de Educação (BR). Resolução CNE/CES n. 03 de 07 de novembro de 2001. 
Diretrizes Curriculares Nacionais para os Cursos de Graduação em Enfermagem. Brasília (DF): MS; 2001.

9. Minayo MCS. O desafio do conhecimento. $11^{\mathrm{a}} \mathrm{ed}$. São Paulo (SP): Hucitec; 2010.

10. Freire P. Pedagogia do oprimido. $50^{a}$ ed. São Paulo (SP): Paz e Terra; 2011.

11. Grosmann P. Un estudio comparado: las fuentes del conocimiento didactico del contenido en la ensenanza del ingles en secundaria. Profesorado. 2005; 9(2):33-2.

12. Waterkemper R, Prado ML. Estratégias de ensinoaprendizagem em cursos de graduação em enfermagem. Avanc Enfermeria. 2011;39(2):234-46.

13. Kleickmann T, Richter D, Kunter M, Elsner J, Besser M, Krauss S, et al. Teachers' content knowledge and pedagogical content knowledge the role of structural differences in teacher education. J Teacher Educ. 2013; 64(1):90-106.

14. Medina Moya JL, Borrasca BJ. Analysis of the pedagogical content knowledge about three university lecturers. Rev Educación. 2013; 360 (1):1-12.
15. Lopes RCC, Sá de Azeredo ZA, Rodrigues RMC. Relational skills: needs experienced by nursing students. Rev Latino-Am Enfermagem. 2012; 20(6):1081-90.

16. Backes VMS, Medina JLM, Prado ML, Menegaz JC, Cunha AP, Francisco BS. Expressões do conhecimento didático do conteúdo de um teacher experimentado de enfermagem. Texto Contexto Enferm [online]. 2013 [acesso 2015 Mar 02]; 22(3):804-10. Dsiponível em: http:/ / www.scielo.br/scielo.php?pid=S010407072013000300029\&script=sci_arttext

17. Pereira WR, Tavares CMM. Práticas pedagógicas no ensino de enfermagem: um estudo na perspectiva da análise institucional. Rev Esc Enferm USP. 2010; 4(4):1077-84.

18. Otto CA, Everett SA. An instructional strategy to introduce pedagogical content knowledge using venn diagrams. J Scienc Teach Educ. 2013; 24(2):391403.

19. Jensen GM, Greenfield B. Ethics education: developing habits of mind through the use of pedagogical content knowledge. Phys Ther Rev. 2012; 17(3):149-56. 